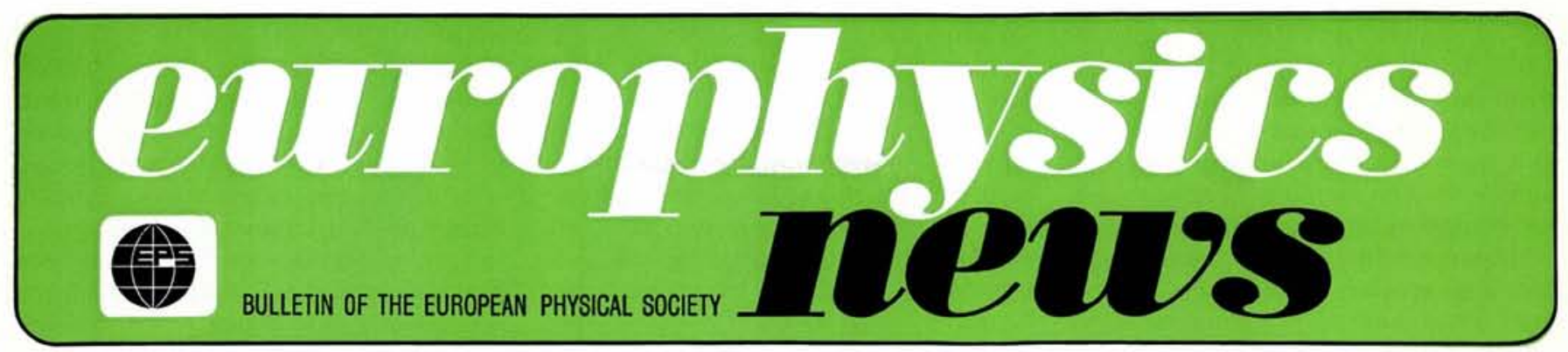

\section{An Appeal to Physicists}

We are continually reminded of the immense forces at work in natural phenomena as, relentlessly, different parts of the world are struck by catastrophe, and populations suffer the devastating effects of famines, floods, hurricanes, tidal waves and so on. As men and women we are sorry for the victims and, perhaps, relieved that we personally have not been involved. But the recent earthquake in Romania touches us also as physicists. In addition to the direct human suffering experienced by the people of Romania and the deprivations that result from the destruction of buildings and the interruptions to essential services, the physicists of Romania have lost much precious equipment and this will be a serious setback to the progress of their research.

This is an occasion when we, as members of EPS, should show the solidarity of European physicists and, in addition to offering our sympathies to our Romanian colleagues, we should try to help them in whatever way we can, to enable the practising physicists and students of that country to continue with their work. There are many ways in which this can be done, and I have proposed to our President, Professor I. Ursu - and I have the full support of Council and the Executive Committee - that the EPS should act as a centre to channel aid to those in need.

I appeal to all our members to consider what assistance they might give and to inform the EPS Secretariat as soon as possible of the form this could take. Gifts of both money and equipment are required urgently. I am sure that I have no need to remind you that we are none of us immune from disaster.

H.B.G. Casimir
Following meetings of the Executive Committee, and various Advisory Committees (including a 2-day session of the Physics and Education Committee) and the Quantum Electronics Divisional Board, Council met in Bruges (or Brugge if you prefer it) on March 24 and 25 to consider the progress made since the Leipzig meeting in April last year.

Before the main business began, Council gave unanimous approval to the appeal, launched by Professor Casimir (see opposite) that Europe's physicists should try to help their colleagues in Romania whose equipment had suffered damage in the recent earthquake. The tandem Van de Graaff generator had been extensively affected and a great deal of electronics equipment associated with their nuclear research had been destroyed both in the earthquake and from a subsequent fire. The President, I. Ursu, on behalf of himself and his Romanian colleagues, expressed his

\section{Practical Arrangements}

The EPS Secretariat is expecting lists from Romania of the material most urgently needed. Copies of these lists will be communicated to the National Societies.

Until further notice, information on material available should be sent to the EPS Secretariat which will then, in collaboration with the Romanian Ambassador in Geneva, take care of the organization of transport. For gifts of money, the bank account of the EPS at the Union de Banques Suisses, 1211 Geneva 11, A/C No. 282.079.30 W (European Physical Society) or Postal Account No. 12-19107 may be used. The words "Help for Romanian Scientists" must appear on the credit advice.
Bruges Report from Council

gratitude to the Council for this demonstration of European solidarity.

\section{Amendment to the Constitution}

Council agreed without debate that the following announcement to members should be made through Europhysics News.

Under Article 18 of the Constitution, "If the Council should decide to amend the Constitution or to expel a member of the Society such decision ... shall be communicated by the Secretariat by registered mail to all members of the Society". The cost of this provision for postage alone has now inflated to the prohibitive level of around Sw. Frs. 4.500 which is an excessive use of the Society's limited funds for a procedural matter. However, the interests of members must be protected so that all reasonable steps must continue to be taken to ensure wide publicity for such changes.

\section{Contents}

Help for Romanian Scientists . Report from Council

Amendment to Constitution . EPS Finances, Conferences, Cooperation.

Education, Publications, People.

Present State of Physics in the People's Republic of Bulgaria Scattering of Thermal Atoms

from Crystal Surfaces.

Mathematics, Mathematical Physics and Developing

Countries

Pluridimensional Radiative

Transfer . . . . . . . . 11

Society News.

4

